\title{
The Grand Budapest Hotel: An Uncommon Adaptation of the World of Yesterday
}

\author{
Ziyan $\mathrm{Li}^{1, *}$

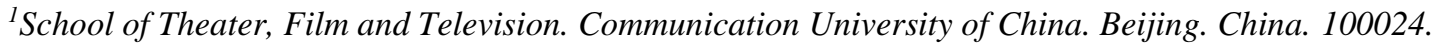 \\ *Corresponding author. Email: 2694652164@qq.com
}

\begin{abstract}
Wes Anderson's film The Grand Budapest Hotel is an unconventional adaptation of writer Zweig's memoir The World of Yesterday and his personal experiences. The film has its own original story but retains the central thrust of the memoir. This thesis will discuss how Wes Anderson represents three important motifs from Zweig's book through the plot of the film, which are the sorrow for the dislocated lives of the refugees, the nostalgia for the spirit of classical Europe and the condemnation of the Nazis. The main subjects of this thesis are the film The Grand Budapest Hotel and the memoir The World of Yesterday. They are going to be researched by a close reading of texts. Some of the ways in which adaptations from literary works to film productions can be found as a result.
\end{abstract}

Keywords: The Grand Budapest Hotel, Wes Anderson, Stefan Zweig, The World of Yesterday, Adaptation

\section{INTRODUCTION}

After the premiere of The French Dispatch of the Liberty, Kansas Evening Sun at the Cannes Film Festival this year, its director Wes Anderson is once again at the center of public opinion. This brings back memories of his masterpiece The Grand Budapest Hotel, which has been regarded as Wes Anderson's best film by a large number of fans and film scholars.

The Grand Budapest Hotel was released in 2014, directed by Wes Anderson and stared by Ralph Fiennes, Saoirse Ronan, Jude Law and other obvious stars. With ingenious composition of movie scenes, candy-like colors and the distinctive camera design, it was widely acclaimed. More noteworthy is its plot, it is an uncommon adaptation of the book The World of Yesterday.

To be more specific, this film mainly tells the story of Mr. Gustave, the elegant and discreet manager of the Grand Budapest Hotel, and Zero, a fledgling lobby boy, who is swept up in a dispute over the inheritance of Mrs. D. The film's plot includes several exciting elements such as murder, prison break, romance and escape. However, as the book The World of Yesterday is a memoir, which tells the real experience of Stefan Zweig, it cannot offer such a dramatic story to meet the demand of a feature film. So, this adaptation from book to film is not a traditional one. It is just closer to the original in terms of motif and style. As one scholar put it: The ways in which the auteur Anderson draws on Zweig have so far been discussed most notably by Whitney Crothers Dilley, who points to Anderson's attempt 'to capture the spirit' of Zweig's oeuvre and traces in particular the anachronistic tone of Anderson's characters to the 'elevated style of Zweig's prose'.[1]

In this case, Wes Anderson finished this uncommon adaptation by originally creating a story but remaining the core of The World of Yesterday. While doing this, the most difficult thing is to express the motifs of The world of yesterday by the original story, which will be the topic of this thesis. This article will be divided into three parts, focusing on three main motifs of the memoir and how Wes Anderson expresses them in The Grand Budapest Hotel. By studying this case, some advice for film adaptations of literary works can be given.

\section{THE SORROW FOR THE DISLOCATED LIVES OF THE REFUGEES}

The first and foremost motif of The world of yesterday is the sorrow for the dislocated lives of the refugees.

In the book, the refugees specifically refer to Jewish people who were forced into exile by wars. Zweig came from a Jewish family, and since he was a teenager, he has faced many controversies related to the Jewish 
people, such as anti-Semitic tendencies and Zionist tendencies. During World WarII, he witnessed the persecution of his compatriot by the Nazis. In the memoir, he conveyed his sadness at the chaotic fate of the Jewish people. As he says in a chapter THE AGONY OF PEACE of his memoirs:

There they crowded, erstwhile university professors, bankers, merchants, landed proprietors, musicians; each ready to drag the miserable ruins of his existence over earth and oceans anywhere, to do and suffer anything, only away, away from Europe, only away! It was a ghostly flock. But my most painful thought was that these fifty tormented people were no more than a skirmish troop preceding an army of five, eight, perhaps ten million Jews who, at the rear, were striking tents and already pressing forward; those millions, first plundered then trampled over by the war, who were waiting for help from charitable institutions, for official permits, and the wherewithal to move on. It was a gigantic mass which, murderously roused and fleeing in panic before the Hitlerite forest fire, besieged the railway stations at every European frontier and filled the jails; the expulsion of a whole people which was denied nationhood but was yet a people which, for two thousand years sought nothing so much as to stop wandering and to rest their feet on quiet, peaceful earth.[2]

He had issued over and over again a sad and helpless interrogation for the misfortune of the Jews, like that:

But why this fate for them and always for them alone? What was the reason, the sense, the aim of this senseless persecution? They were driven out of lands but without a land to go to. They were repulsed but not told where they might be accepted. They were held blameful but denied means of expiation. And thus, with smarting eyes, they stared at each other on their flight: Why I? Why you? How do you and I who do not know each other, who speak different languages, whose thinking takes different forms and who have nothing in common happen to be here together? Why any of us? And none could answer. Even Freud, the clearest seeing mind of this time, with whom I often talked in those days, was baffled and could make no sense out of the nonsense. Who knows but that Judaism because of its mysterious survival may not, in its ultimate significance, constitute a reiteration of Job's eternal cry to God, so that it may not be quite forgotten on earth.[3]

During the process of the adaptation, the motif is still expressed, but it is further broadened. Wes Anderson not only shows the suffering of Jewish refugees, but attempts to show the suffering of all refugees, by character setting and plotting of the movie.

Firstly, one of the main characters of The Grand Budapest Hotel, Zero, is in fact a refugee. Zero doesn't have obvious racial characteristics. As one scholar put it: there is little apart from Zero's dark features that gives away his cultural and ethnic heritage. Jewish it is not, as Zero's surname, Moustafa, testifies, which if anything, sounds Bosnian, Turkish or maybe Arabic.[4] Therefore, he is more like a microcosm of all refugees. In the film, his refugee status and suffering in exile are shown to audiences by the lines when Mr. Gustave asked him why he had come to the Grand Budapest Hotel after the prison break. "Well, you see, my father was murdered and the rest of my family were executed by firing squad. Our village was burned to the ground and those who managed to survive were forced to flee. I left because of the war.’[5]

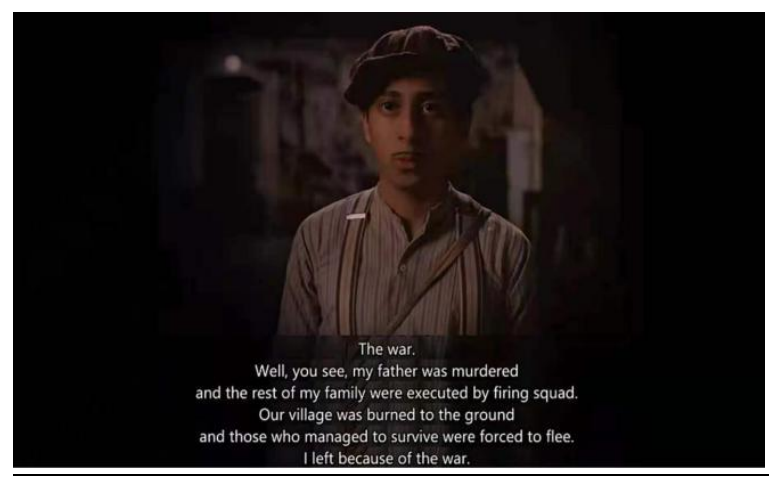

Figure 1 Zero's answer

Secondly, throughout most of the film, two protagonists were on the lam. The director wanted to show the displacement of the Jewish people in this way. Coincidentally, "on the lam" is also a recurring motif in Wes Anderson's films. For example, the film Moonrise Kingdom tells the story of a twelve-year-old couple who elope and escape being tracked down from the whole town. And also, the film Isle of Dogs tells the story of a little boy who escapes his home and goes to a deserted island to rescue his dog.

\section{THE NOSTALGIA FOR THE SPIRIT OF CLASSICAL EUROPE}

Zweig 's nostalgia for the Europe of the past is evident throughout the book, which becomes another motif of The World of Yesterday. Wes Anderson once admitted in an interview that he wanted to follow the old European sentiment of The World of Yesterday in the movie. The Grand Hotel is a wonderful tool for expression of this motif. The pink castle hotel in Anderson's film with its allusions to Zweig's villa in Salzburg as well as to European grand hotels - the Pupp in Carlsbad (Karlovy Vary), the Hotel National in Lucerne - and perhaps to the rose Palácio da Princesa Isabel in Petrópolis, Brazil, represents Zweig's world of yesterday. [6]When showing the exterior of the hotel, Wes Anderson has succeeded in representing the transformation of Europe with different main colors of the picture, from the delicate pink to the old yellow. 


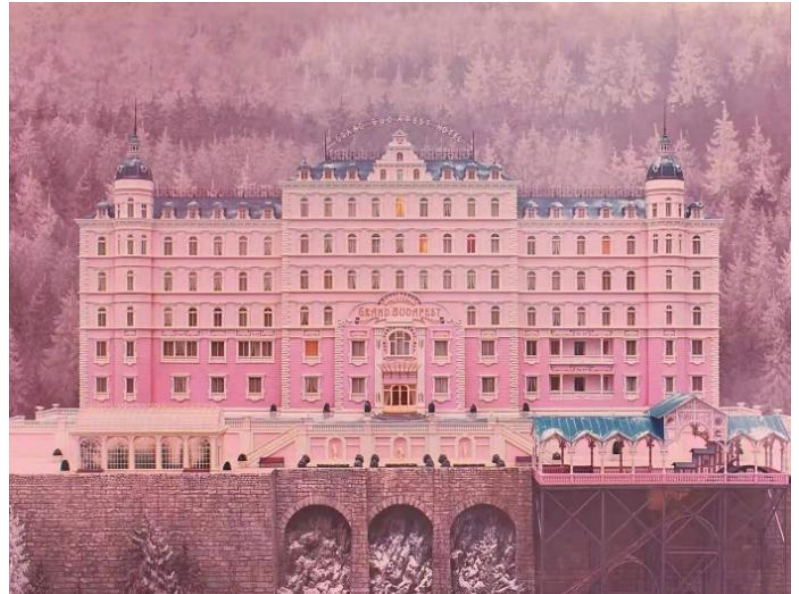

Figure 2 the Grand Budapest Hotel in the 30s

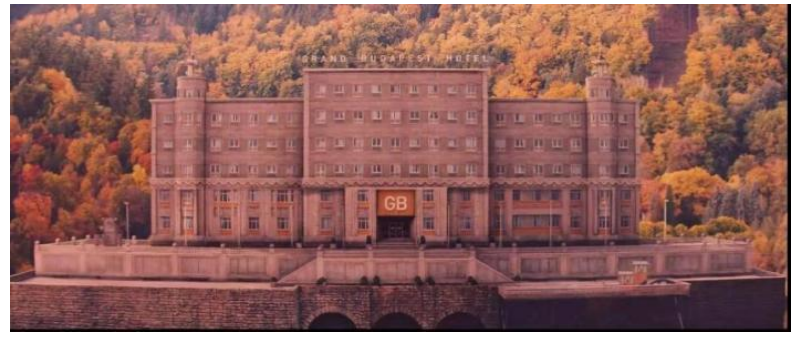

Figure 3 the Grand Budapest Hotel in 60s

Wes Anderson's presentation of this motif is also evident in many details. For instance, Zweig described in his book that in his teenage years, Europeans still valued maturity and stability so much, in that case young people found ways to make themselves look older, in order to gain the respect of others. Here is his description:

Whereas today, in our changed state of affairs, those of forty seek to look thirty, and those of sixty wish to seem forty, and youth, energy, determination and selfconfidence recommend and advance a man, in that age of security everyone who wished to get ahead was forced to attempt all conceivable methods of masquerading in order to appear older. The newspapers recommended preparations which hastened the growth of the beard, and twenty-four- and twenty-five-year-old doctors, who had just finished their examinations, wore mighty beards and gold spectacles even if their eyes did not need them, so that they could make an impression of "experience" upon their first patients. Men wore long black frock coats and walked at a leisurely pace, and whenever possible acquired a slight embonpoint, in order to personify the desired sedateness; and those who were ambitious strove, at least outwardly, to belie their youth, since the young were suspected of instability.[7]

The above even used details such as dress and pace to illustrate the value placed on maturity in olden times in Europe. In the movie, the young Zero will paint himself two mustaches every day to make himself look more mature. This can be said to be a translation of the text in images.

\section{THE CONDEMNATION OF THE NAZIS}

The third motif that should be mentioned is the condemnation of the Nazis. Zweig accused the Nazis of destroying the spirit of classical Europe countless times in The World of Yesterday. He pointed out that the previous Europe was a free world, where one could go anywhere without being checked or suspected and also pointed out that at that time people believed that countries could unite together. But from the outbreak of World War I, this beautiful situation began to be shattered, and in World War II, and Hitler came to power with cruel measures to completely kill old Europe.

This is shown in the film about the atrocity of Mrs. D's son Dmitri and the death of Mr. Gustav. We can clearly see that the flag brought by Dmitri, is very much like the Nazi flag. Besides, the final scene of the film suddenly shifts to black and white, and instead of listening to Mr. Gustav's advice, as they did last time, the loaded soldiers shoot him dead. For a film in which the main body of the story has a happy ending, this death of a major character is obviously a bit abrupt and catches the audience off guard, but maybe this is exactly the effect that Wes Anderson wanted to achieve. Because in Zweig's memoirs, the Nazis' disruption of the good life in Europe also caught people off guard in this way.

There are lots of films that express this type of motif, such as Schindler's List directed by Steven Spielberg, La Vita è bella directed by Roberto Remigio Benigni and so on. But unlike the realistic approach used in many films, Wes Anderson is employing a political metaphor in this film to express the indictment of the Nazis, which is more like The Great Dictator directed by Charlie Chaplin.

\section{CONCLUSION}

To sum up, the film The Grand Budapest Hotel has accomplished an unusual adaptation of the memoir The World of Yesterday. In a way, the creators of the two works, Zweig and Wes Anderson, share the same heart.

Wes Anderson masterly uses his original story to express the motifs of the memoir. The three main motifs include the sorrow for the dislocated lives of the Jewish people, the nostalgia for the spirit of classical Europe and the condemnation of the Nazis.

From past film and television adaptations of literary classics, we can divide the adaptation strategies of each work into two categories. The first type of strategy is "faithfulness to the original", which follows the plot and character set of the original and uses a great deal of meticulous research to support the details of the film and television production, in an attempt to restore the literary classic in the minds of readers; the second type 
of strategy is "innovation", which does not take the restoration of the original as its main goal. They intercept a fragment of the literary work, magnifies and renders it, or change the narrative perspective, or even borrows only certain elements from the original to create a new story.

The Grand Budapest Hotel is undoubtedly an example of the second strategy applied with success. Wes Anderson's approach is worthy of study by directors who want to do literary adaptations afterward.

\section{ACKNOWLEDGMENTS}

Through a lot of hard work and a lot of help, I finally finished my thesis. First of all, I would like to extend my sincere appreciation to professor David Howard, who is the mentor of the course "Cultures in Films: Where Story and Culture Meet". I learned about script writing and cultural studies in the course, and received guidance on my thesis from him. In addition, I also need to express my gratitude to my teaching assistant Lillian Lyu and my thesis advisor Mandy Han. They gave me plenty of suggestions about my choice of the topic and search of information.

\section{REFERENCES}

[1]Dilley, Whitney Crothers. "10 Literary Influence and Memory: Stefan Zweig and The Grand Budapest Hotel'. The Cinema of Wes Anderson, New York Chichester, West Sussex: Columbia University Press, 2017, pp. 185.

[2] Stefan Zweig. The World of Yesterday. University of Nebraska Press · Lincoln, 1964, pp.426-427

[3] Stefan Zweig. The World of Yesterday. University of Nebraska Press · Lincoln, 1964, pp.428-429

[4] Warren Buckland. Wes Anderson's Symbolic Storyworld: A Semiotic Analysis. Bloomsbury Publishing Inc, 2019, pp.162

[5]Wes Anderson. The Grand Budapest Hotel.2014

[6] Preuschoff, Nikolai. "His world had vanished long before he entered it": Wes Anderson's Homage to Stefan Zweig. Adaptation Considered as a Collaborative Art, 2020, pp.150

[7] Stefan Zweig. The World of Yesterday. University of Nebraska Press · Lincoln, 1964, pp.34. 